\title{
Correction to: Understanding Harm and its Moral Significance
}

\section{Matthew Hanser ${ }^{1}$}

Published online: 6 August 2019

(C) Springer Nature B.V. 2019

\section{Correction to: Ethical Theory and Moral Practice https://doi.org/10.1007/s10677-019-09996-4}

The original version of this article unfortunately contained a mistake. Section Heading numbers (i.e. 1, 2, 3, 4, 5, 6, and 7) were erroneously removed in the article.

The original article has been corrected.

Publisher's Note Springer Nature remains neutral with regard to jurisdictional claims in published maps and institutional affiliations.

The online version of the original article can be found at https://doi.org/10.1007/s10677-019-09996-4

Matthew Hanser

hanser@philosophy.ucsb.edu

1 Department of Philosophy, University of California, Santa Barbara, CA 93106, USA 